\title{
Characterization of Two Fructose Bisphosphatase Isoenzymes from the Hydrogen Bacterium Nocardia opaca 1b
}

\author{
By T. AMACHI* AND B. BOWIEN \\ Institut für Mikrobiologie der Universität Göttingen, Grisebachstrasse 8, \\ D-3400 Göttingen, Federal Republic of Germany
}

(Received 24 November 1978)

\begin{abstract}
Two distinct forms of fructose 1,6-bisphosphatase, designated form $\mathrm{A}$ and form $\mathrm{B}$, have been partially purified from autotrophically grown cells of the hydrogen bacterium Nocardia opaca 1 b. Form A was present when the organism was grown under autotrophic conditions but was not synthesized during heterotrophic growth. Form B was detected in both autotrophically and heterotrophically grown organisms, suggesting that it is a constitutive enzyme. The molecular weights were estimated to be 140000 for form A and 190000 for form B. Both purified enzymes showed fructose bisphosphatase as well as sedoheptulose bisphosphatase activity, with $\mathrm{pH}$ optima of 8.2 and 8.8 to 9.0 for forms $\mathrm{A}$ and $\mathrm{B}$, respectively. The ratio of fructose bisphosphatase to sedoheptulose bisphosphatase activity was 0.6 for form $\mathrm{A}$ and about 4.5 for form $\mathrm{B}$. The enzymes required $\mathrm{Mg}^{2+}$ for activity; $\mathrm{Mn}^{2+}$ could only partially replace $\mathrm{Mg}^{2+}$. Form A was inhibited by ATP and ribulose bisphosphate. AMP exerted a strong allosteric inhibition on form $B$ which was also inhibited by $\mathrm{NAD}^{+}$and NADH. Phosphoenolpyruvate activated form B. On the basis of these results, different physiological roles for the two forms of fructose bisphosphatase are suggested.
\end{abstract}

\section{INTRODUCTION}

In the gluconeogenic pathway of heterotrophic organisms a number of enzyme reactions are involved which also occur in the Calvin cycle for the reductive assimilation of carbon dioxide in autotrophs. In both metabolic pathways, fructose bisphosphatase (EC 3 1.3.11), catalysing the hydrolytic cleavage of fructose 1,6-bisphosphate to fructose 6-phosphate and inorganic phosphate, is a principal regulatory enzyme (Bassham, 1971; Horecker et al., 1975). The enzymes isolated from animal (Taketa \& Pogell, 1965), plant (Racker \& Schroeder, 1958) and bacterial sources (Fraenkel et al., 1966; Springate \& Stachow, 1972a) resemble each other in major characteristics but exhibit distinct regulatory properties which seem to suit their different physiological functions in heterotrophic and autotrophic metabolism. While fructose bisphosphatases from mammalian tissues and the majority of heterotrophic bacteria are strongly inhibited by AMP (Taketa \& Pogell, 1965; Opheim \& Bernlohr, 1975), fructose bisphosphatase from plant chloroplasts (Buchanan et al., 1971) as well as photo- and chemolithoautotrophic bacteria (Joint et al., 1972; Abdelal \& Schlegel, 1974) are insensitive to AMP. Furthermore, the chloroplast fructose bisphosphatase and a related enzyme activity, sedoheptulose bisphosphatase, which is also part of the Calvin cycle, are reductively activated in the light (Buchanan et al., 1976; Schürmann \& Wolosiuk, 1978).

Very little information is available on whether facultatively autotrophic bacteria synthesize fructose bisphosphatases with different regulatory properties during autotrophic and

* Permanent address: Suntory Ltd, Central Research Institute, Osaka 618, Japan. $0022-1287 / 79 / 0000-8474 \$ 02.00$ (C) 1979 SGM 
heterotrophic growth. The purpose of this study was to examine the nature of the fructose bisphosphatases from autotrophically and heterotrophically grown cells of the facultatively chemolithoautotrophic hydrogen bacterium Nocardia opaca strain $1 \mathrm{~b}$. We report here the separation, partial purification and characterization of two bisphosphatase isoenzymes, both of which also exhibited a sedoheptulose bisphosphatase activity. Their differential synthesis and catalytic properties suggest a specific physiological role for each of the isoenzymes.

\section{METHODS}

Organism. Nocardia opaca strain 1b, DSM 427 (Aggag \& Schlegel, 1973) was obtained from the culture collection of this institute.

Chemicals. Most enzymes, bovine serum albumin, most sugar phosphates and other biochemicals were from Boehringer. Ammediol (2-amino-2-ethyl-1,3-propanediol), phenylmethanesulphonyl fluoride, ribulose 1,5-bisphosphate, ribulose 5-phosphate and sedoheptulose 1,7-bisphosphate were from Sigma; urease (EC 3.5.1.5) was from Miles-Seravac, Maidenhead, Berks. All other chemicals were obtained from Merck.

Culture conditions and preparation of crude extracts. The organism was grown at $30{ }^{\circ} \mathrm{C}$ in a 101 fermenter (Braun, Melsungen, West Germany) using the mineral salts medium of Schlegel et al. (1961). Autotrophic cultures were supplied with a gas mixture of $\mathrm{H}_{2} / \mathrm{O}_{2} / \mathrm{CO}_{2}\left(8: 1: 1\right.$, by vol.) at $500 \mathrm{ml} \mathrm{min}^{-1}$. For heterotrophic growth under air (aeration at $21 \mathrm{~min}^{-1}$ ), the medium was supplemented with $0.5 \%(\mathrm{w} / \mathrm{v})$ organic substrate. The maximum specific growth rate $\left(\mu_{\max }\right)$ was $0.092 \mathrm{~h}^{-1}$ for autotrophic growth, and $0.103 \mathrm{~h}^{-1}$ and $\mathbf{0 . 2 7 7} \mathrm{h}^{-1}$ for heterotrophic growth with pyruvate and fructose, respectively. Organisms were harvested during mid-exponential phase by centrifugation and washed with $0.05 \mathrm{M}-\mathrm{Tris} / \mathrm{HCl}$ buffer $(\mathrm{pH} 7 \cdot 6)$ containing $2.5 \mathrm{~mm}-\mathrm{MgCl}_{2}, 0.1 \mathrm{~mm}$-EDTA, $0.1 \mathrm{~mm}$-phenylmethanesulphonyl fluoride and $1 \mathrm{~mm}$-dithioerythritol (Tris/ MEPD buffer).

The temperature was maintained at 0 to $4{ }^{\circ} \mathrm{C}$ throughout the preparation of crude extracts and the purification procedure. Organisms ( 2 to $100 \mathrm{~g}$ wet wt) were suspended at a concentration of $0.33 \mathrm{~g} \mathrm{ml}^{-1}$ in Tris/MEPD buffer and ruptured by passing twice through a French pressure cell at $140 \mathrm{MPa}$. The homogenate was centrifuged at $20000 \mathrm{~g}$ for $20 \mathrm{~min}$ to remove unbroken cells and debris and the supernatant was recentrifuged at $140000 \mathrm{~g}$ for $60 \mathrm{~min}$. The resulting supernatant fraction contained all the fructose/sedoheptulose bisphosphatase activity and was used as crude extract. Protein was determined by Lowry's method.

Separation of the fructose bisphosphatase isoenzymes. The protein concentration of the crude extract from autotrophically grown organisms was adjusted to $20 \mathrm{mg} \mathrm{ml}^{-1}$ by dilution with Tris/MEPD buffer and the extract was taken to $45 \%$ saturation by adding saturated $\left(\mathrm{NH}_{4}\right)_{2} \mathrm{SO}_{4}$ solution $(\mathrm{pH} \mathrm{7.6)}$. The precipitated fraction contained virtually all the activity of the form A isoenzyme and was dissolved in a minimal volume of Tris/MEPD buffer. A second protein fraction, precipitating between 45 and $50 \%$ saturation with $\left(\mathrm{NH}_{4}\right)_{2} \mathrm{SO}_{4}$, showed no fructose/sedoheptulose bisphosphatase activity and was therefore discarded. Protein precipitating between 50 and $80 \%\left(\mathrm{NH}_{4}\right)_{2} \mathrm{SO}_{4}$ saturation contained the form $\mathrm{B}$ isoenzyme; it was collected by centrifugation and dissolved in a minimal volume of Tris/MEPD buffer. Both enzyme solutions were dialysed against the same buffer. On $\left(\mathrm{NH}_{4}\right)_{2} \mathrm{SO}_{4}$ fractionation of crude extracts from heterotrophically grown organisms, fructose bisphosphatase activity was exclusively found in the fraction precipitating between 50 and $80 \%$ salt saturation. The precipitate was treated as described before.

Partial purification of form $A$ and form $B$ fructose bisphosphatase.

(i) DEAE-Sephadex chromatography. The dialysed enzyme solutions from the $\left(\mathrm{NH}_{4}\right)_{2} \mathrm{SO}_{4}$ fraction, supplemented with $2 \mathrm{~mm}$-fructose bisphosphate, were separately applied to a DEAE-Sephadex A-50 column $(2.5 \times 30 \mathrm{~cm})$ equilibrated with Tris/MEPD buffer containing $2 \mathrm{~mm}$-fructose bisphosphate. The column was first washed with $250 \mathrm{ml}$ of the equilibrating buffer and the protein was then eluted with 1.51 of a linear gradient of $\mathrm{KCl}(0$ to $0.5 \mathrm{M})$ in the same buffer at a flow rate of $50 \mathrm{ml} \mathrm{h}^{-1}$. Form A fructose bisphosphatase was eluted between 0.22 and $0.29 \mathrm{M}-\mathrm{KCl}$, while the form $\mathrm{B}$ isoenzyme was eluted between 0.32 and $0.42 \mathrm{M}-\mathrm{KCl}$. Fructose bisphosphatase from heterotrophically grown organisms was eluted at exactly the same ionic strength as the form $\mathbf{B}$ isoenzyme. The enzyme fractions were concentrated by $\left(\mathrm{NH}_{4}\right)_{2} \mathrm{SO}_{4}$ precipitation (80\% saturation), dialysed against Tris/MEPD buffer and re-chromatographed on the same column. Elution was with 1.51 linear gradients of $\mathrm{KCl}$ in Tris/MEPD buffer containing $2 \mathrm{~mm}-$ fructose bisphosphate. The concentration ranges of the gradients were from 0.15 to $0.35 \mathrm{M}-\mathrm{KCl}$ for form $\mathrm{A}$ and from $0 \cdot 2$ to $0.4 \mathrm{M}-\mathrm{KCl}$ for form $\mathrm{B}$ or the enzyme from heterotrophically grown organisms. Again, form $A$ was eluted between 0.22 and $0.29 \mathrm{M}-\mathrm{KCl}$ whereas form $\mathrm{B}$ or the enzyme from heterotrophically 
grown organisms was eluted between 0.32 and $0.36 \mathrm{M}-\mathrm{KCl}$. The protein of the enzyme solutions was concentrated by $\left(\mathrm{NH}_{4}\right)_{2} \mathrm{SO}_{4}$ precipitation ( $80 \%$ saturation).

(ii) Back-extraction with ammonium sulphate. The enzyme preparations from the previous step were extracted stepwise with $\left(\mathrm{NH}_{4}\right)_{2} \mathrm{SO}_{4}$ solutions (prepared in Tris/MEPD buffer containing 2 mM-fructose bisphosphate) in 2 to $5 \%$ decrements ranging between 75 and $40 \%$ saturation. Two successive extractions, each of $2 \mathrm{ml}$, were employed at each step. Form A dissolved between 45 and $42 \%$ saturation, form $B$ or the enzyme from heterotrophically grown organisms between 65 and $58 \%$ saturation.

(iii) Sephadex G-200 gel filtration. The enzyme solutions from the $\left(\mathrm{NH}_{4}\right)_{2} \mathrm{SO}_{4}$ back-extraction were applied to a Sephadex G-200 column $(2.5 \times 95 \mathrm{~cm}$; void vol. $190 \mathrm{ml})$ equilibrated with Tris/MEPD buffer containing $2 \mathrm{~mm}$-fructose bisphosphate and eluted with the same buffer at a flow rate of $10 \mathrm{ml} \mathrm{h}^{-1}(2 \cdot 2 \mathrm{ml}$ fractions). The elution volume for form B or the enzyme from heterotrophically grown organisms was $261 \mathrm{ml}$ and that for form A was $279 \mathrm{ml}$. To estimate the molecular weights of the enzymes (Reiland, 1971), the Sephadex G-200 column was calibrated with the following standards ( $2 \mathrm{mg}$ of each protein): urease (mol. wt 483000), catalase (EC 1.11.1.6; 247000), aldolase (EC 4.1.2.13;158000), bovine serum albumin (68000) and cytochrome $c(12500)$. Fractions with similar specific activity were combined, concentrated by $\left(\mathrm{NH}_{4}\right)_{2} \mathrm{SO}_{4}$ precipitation ( $80 \%$ saturation), then dissolved in a minimal volume of Tris/MEPD buffer and finally dialysed against the same buffer. The enzyme solutions could be stored at $-20{ }^{\circ} \mathrm{C}$ for several weeks without appreciable loss of activity.

Enzyme assays. Fructose bisphosphatase activity was measured either spectrophotometrically at $334 \mathrm{~nm}$ in a coupled assay by following the rate of reduction of $\mathrm{NADP}^{+}$, or colorimetrically based on the release of inorganic phosphate. Both assay procedures gave identical enzyme activities. Sedoheptulose bisphosphatase activity was determined only by the colorimetric assay. The stoicheiometry of the sedoheptulose bisphosphatase reaction, i.e. the equimolar formation of sedoheptulose 7-phosphate and inorganic phosphate from sedoheptulose 1,7-bisphosphate, was established as described by Rosen (1966).

The standard reaction mixture for the spectrophotometric assay (final volume $0.60 \mathrm{ml}$ ) contained

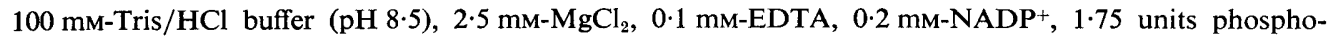
glucose isomerase (EC 5.3.1.9), 1.4 units glucose-6-phosphate dehydrogenase (EC 1.1.1.49), 0.1 mMfructose bisphosphate and an appropriate amount of enzyme. The reaction was started by the addition of the enzyme and the formation of NADPH was followed in a Zeiss PL4 spectrophotometer connected to a Servogor RE511 recorder.

The standard reaction mixture for the colorimetric assay (final volume $0.50 \mathrm{ml}$ ) contained $100 \mathrm{~mm}$-Tris/

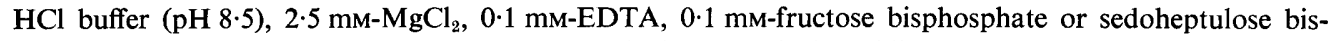
phosphate and enzyme. The reaction was stopped after $2.5 \mathrm{~min}$ by adding $0.1 \mathrm{ml}$ of $2.5 \mathrm{M}-\mathrm{H}_{2} \mathrm{SO}_{4}$ and the precipitate, if any, was removed by centrifugation. The amount of inorganic phosphate in the supernatant was determined according to Ames (1966). Controls without enzyme or without substrate were included. All enzyme assays were performed at $30^{\circ} \mathrm{C}$. One unit of enzyme is defined as the amount catalysing the hydrolysis of $1 \mu \mathrm{mol}$ fructose 1,6-bisphosphate or sedoheptulose 1,7-bisphosphate $\min ^{-1}$ at $30^{\circ} \mathrm{C}$.

\section{RESULTS}

\section{Studies with crude extracts}

Crude extracts of autotrophically grown organisms contained both fructose bisphosphatase and sedoheptulose bisphosphatase activity in the ratio 1.4:1 (Table 1). In organisms grown with pyruvate or fructose, sedoheptulose bisphosphatase was almost completely absent while fructose bisphosphatase was only partially depressed. Preliminary studies on the regulatory properties of the enzymes indicated that AMP exerted a much stronger inhibitory effect on the fructose bisphosphatase activity from heterotrophically grown organisms. These results suggested that different fructose bisphosphatases exist in $N$. opaca grown under autotrophic and heterotrophic conditions. Another question raised by these preliminary observations was whether the sedoheptulose bisphosphatase activity detected in autotrophically grown organisms was due to a separate specific enzyme or was the property of a single protein catalysing both the fructose bisphosphatase and sedoheptulose bisphosphatase reactions. 


\section{Table 1. Specific activities of fructose bisphosphatase and sedoheptulose bisphosphatase in N. opaca under different growth conditions}

Activities were determined colorimetrically by the inorganic phosphate assay as described in Methods. Specific activities are expressed as units (mg protein) ${ }^{-1}$.

Growth conditions (carbon source)
Autotrophic (carbon dioxide)
Heterotrophic (pyruvate)
Heterotrophic (fructose)

$\begin{array}{cc}\begin{array}{c}\text { Fructose } \\ \text { bisphosphatase }\end{array} & \begin{array}{c}\text { Sedoheptulose } \\ \text { bisphosphatase }\end{array} \\ 0.133 & 0.095 \\ 0.080 & <0.001 \\ 0.053 & 0.001\end{array}$

Separation and partial purification of two fructose bisphosphatase isoenzymes

The two fructose bisphosphatase isoenzymes, designated form $\mathrm{A}$ and form $\mathrm{B}$, were effectively separated by a simple ammonium sulphate fractionation of crude extracts from autotrophically grown organisms at $45 \%$ salt saturation. The form A isoenzyme, which catalysed the hydrolysis of the phosphate group on C-1 of sedoheptulose 1,7-bisphosphate in addition to that of fructose 1,6-bisphosphate, comprised about $60 \%$ of the total fructose bisphosphatase activity in autotrophically grown organisms. Crude extracts from organisms grown heterotrophically on pyruvate or fructose only contained fructose bisphosphatase which precipitated between 50 and $80 \%$ ammonium sulphate saturation. Further purification of the isoenzymes was achieved by DEAE-Sephadex A-50 chromatography, back-extraction with ammonium sulphate and gel filtration on Sephadex G-200 (Table 2). The purified enzymes were free of detectable amounts of aldolase. Both crude fractions and purified preparations of form $\mathrm{A}$ had fructose bisphosphatase as well as sedoheptulose bisphosphatase activity. The ratio of fructose bisphosphatase to sedoheptulose bisphosphatase activity remained constant at approximately 0.6 during the last purification steps. In contrast, form B showed no sedoheptulose bisphosphatase activity in crude fractions but acquired this activity in the course of the purification procedure. However, the ratio of fructose bisphosphatase to sedoheptulose bisphosphatase activity was never less than about $4 \cdot 5$.

The fructose bisphosphatase from pyruvate-grown organisms was purified by the same procedure as that described for form B. Furthermore, if purified form B was mixed with crude extracts from pyruvate-grown organisms only one enzyme activity was subsequently recovered. This suggested that form B from autotrophically grown organisms was identical with fructose bisphosphatase from heterotrophically grown organisms. These two enzymes were identical with respect to all properties tested, lending further support to this suggestion.

\section{Properties of the partially purified isoenzymes}

Molecular weight. The molecular weights of the isoenzymes were estimated by gel filtration on Sephadex G-200 using urease, catalase, aldolase, bovine serum albumin and cytochrome $c$ as standards. Molecular weights of 140000 for form A and 190000 for form B were obtained from the standard calibration curve (results not shown). The molecular weights of the enzymes did not change during purification.

Effect of $\mathrm{pH}$ and EDTA. In Tris/ $\mathrm{HCl}$ or Ammediol/HCl buffers, the fructose bisphosphatase as well as the sedoheptulose bisphosphatase activity of form A was optimal at $\mathrm{pH} 8 \cdot 2$, whereas form B showed maximal activity between $\mathrm{pH} 8.8$ and $9 \cdot 0$. The activity of both isoenzymes was increased about threefold by EDTA at concentrations higher than $10 \mu \mathrm{M}$ and $3 \mu \mathrm{M}$ for form $\mathrm{A}$ and form $\mathrm{B}$, respectively, but the $\mathrm{pH}$ optima did not change. EDTA concentrations above $150 \mu \mathrm{M}$ were inhibitory.

Substrate and cofactor specificity. To differentiate the two isoenzymes from non-specific phosphatases, a number of sugar phosphates were tested for their ability to serve as 


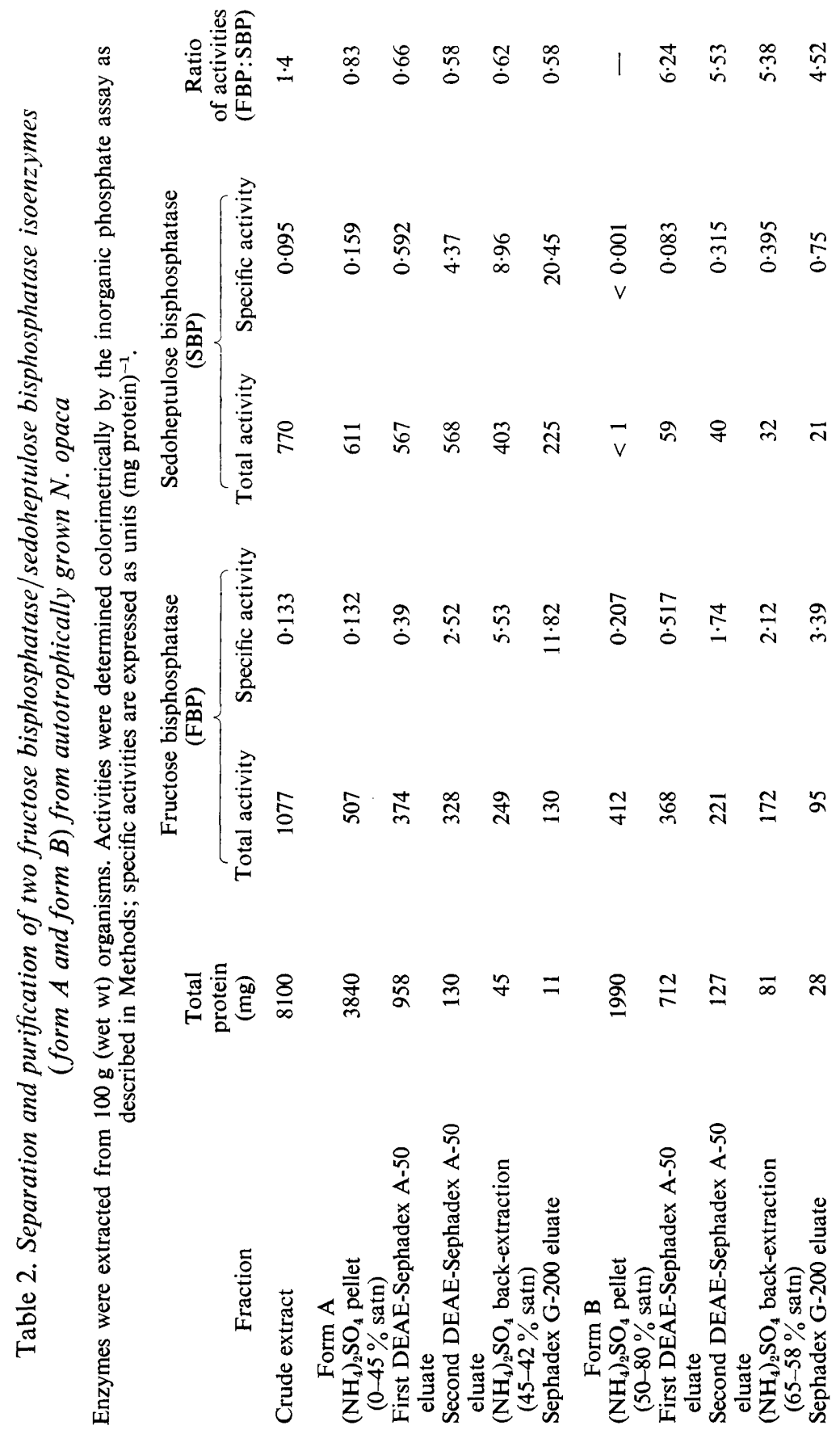




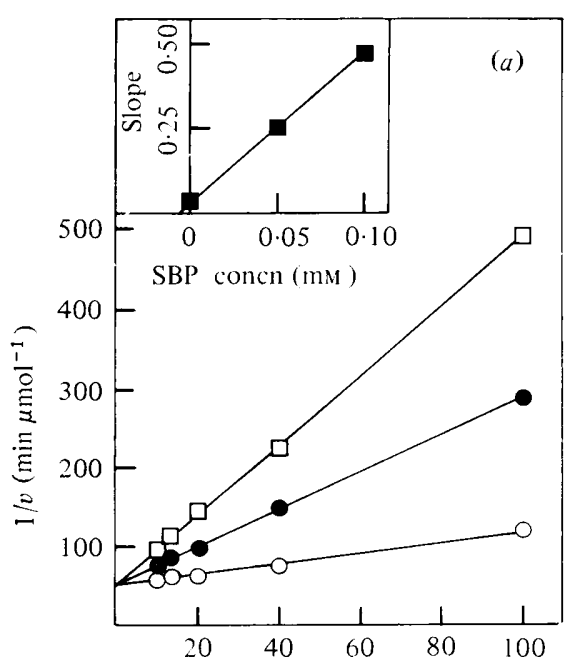

1/Fructose bisphosphate concn $\left(\mathrm{mm}^{-1}\right)$

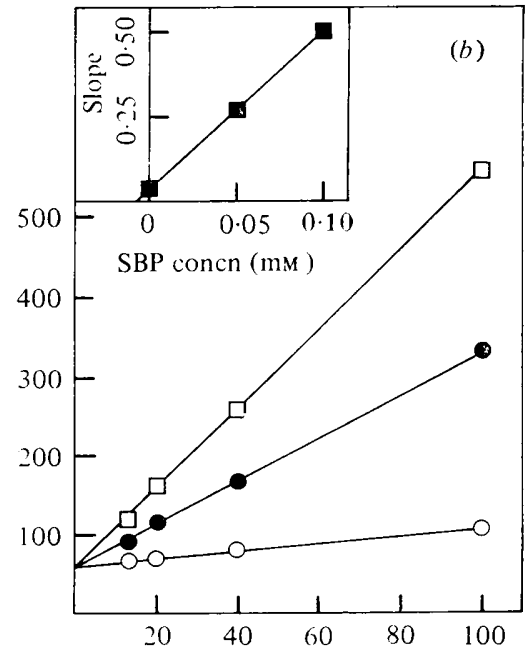

$1 /$ Fructose bisphosphate concn ( $\left.\mathrm{mm}_{-}{ }^{1}\right)$

Fig. 1. Influence of sedoheptulose bisphosphate on the fructose bisphosphatase activities of form A $(a)$ and form B $(b)$ isoenzymes. Double-reciprocal plots of reaction velocity versus fructose bisphosphate concentration are shown for fixed sedoheptulose bisphosphate concentrations of $0(\bigcirc), 0.05 \mathrm{~mm}(\odot)$ and $0.10 \mathrm{~mm}(\square)$. The insets show replots of the slopes versus sedoheptulose bisphosphate (SBP) concentration. Activities were determined at $\mathrm{pH} 8.5$ using the spectrophotometric assay.

Table 3. Differential inhibition of the two fructose bisphosphatase isoenzymes from $N$. opaca

Fructose bisphosphatase activities were determined colorimetrically by the inorganic phosphate assay at $\mathrm{pH} 8 \cdot 5$. Excess $\mathrm{MgCl}_{2}$ in equivalent amounts was added to the reaction mixture when ATP was present.

\begin{tabular}{|c|c|c|c|}
\hline \multirow[b]{2}{*}{ Effector } & \multirow{2}{*}{$\begin{array}{l}\text { Concn } \\
(\mathrm{mm})\end{array}$} & \multicolumn{2}{|c|}{ Inhibition $(\%)$} \\
\hline & & Form A & Form B \\
\hline ATP & $\begin{array}{l}0 \cdot 25 \\
1.0\end{array}$ & $\begin{array}{l}31 \\
70\end{array}$ & $\begin{array}{r}9 \\
49\end{array}$ \\
\hline AMP & $\begin{array}{l}0 \cdot 025 \\
0 \cdot 10\end{array}$ & $\begin{array}{l}0 \\
9\end{array}$ & $\begin{array}{r}87 \\
100\end{array}$ \\
\hline $\mathrm{NAD}^{+}$ & $1 \cdot 0$ & 0 & 67 \\
\hline NADH & $1 \cdot 0$ & 20 & 83 \\
\hline Ribulose 1,5 -bisphosphate & $\begin{array}{l}0 \cdot 25 \\
1 \cdot 0\end{array}$ & $\begin{array}{l}24 \\
48\end{array}$ & $\begin{array}{l}0 \\
3\end{array}$ \\
\hline
\end{tabular}

substrates. Both enzymes specifically cleaved fructose 1,6-bisphosphate and sedoheptulose 1,7-bisphosphate yielding fructose 6-phosphate or sedoheptulose 7-phosphate, respectively, and inorganic phosphate. Neither enzyme hydrolysed glucose 1-phosphate, glucose 6-phosphate, glucose 1,6-bisphosphate, ribulose 5-phosphate, ribulose 1,5-bisphosphate, fructose 1-phosphate or fructose 6-phosphate in the inorganic phosphate assay at pH 8.5 or 6.0 . The enzymes required $\mathrm{Mg}^{2+}$ for activity. Of other divalent cations tested, only $\mathrm{Mn}^{2+}$ could partially replace $\mathrm{Mg}^{2+}$. At $0.5 \mathrm{mM}-\mathrm{Mn}^{2+}$ the reaction velocity for form A was $50 \%$ and for form B $67 \%$ of that measured with $0.5 \mathrm{mM}-\mathrm{Mg}^{2+} . \mathrm{Mn}^{2+}$ concentrations higher than $0.5 \mathrm{~mm}$ inhibited both enzymes.

Kinetic data. Kinetic parameters were determined in initial velocity studies. Both enzymes exhibited normal Michaelis-Menten kinetics with respect to their substrates fructose bis- 


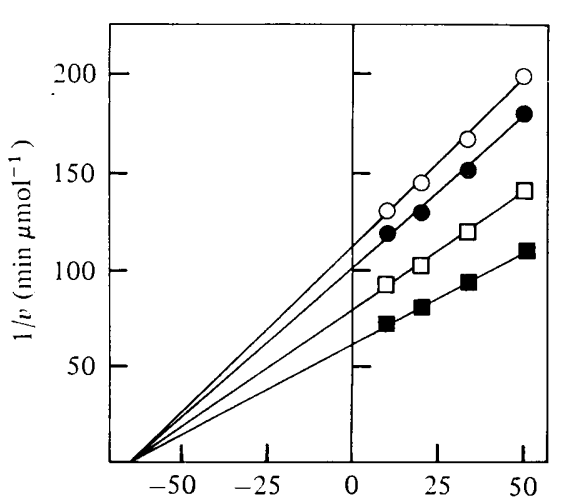

1/Fructose bisphosphate concn $\left(\mathrm{mm}^{-1}\right)$

Fig. 2

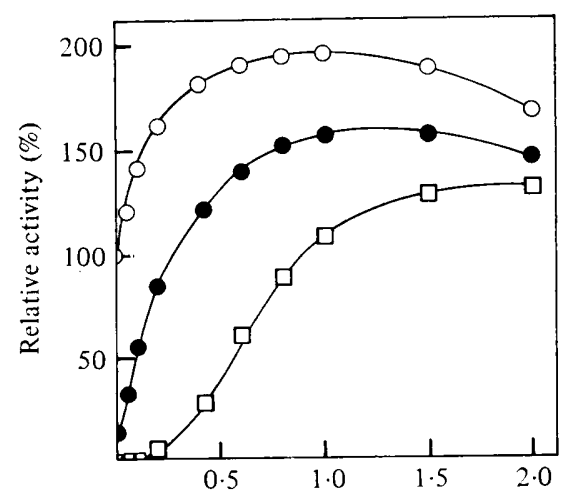

Phosphoenolpyruvate concn (mM)

Fig. 3

Fig. 2. Influence of phosphoenolpyruvate on the fructose bisphosphatase activity of the form $B$ isoenzyme. Double-reciprocal plots of reaction velocity versus fructose bisphosphate concentration are shown for fixed phosphoenolpyruvate concentrations of $0(\bigcirc), 0.05 \mathrm{~mm}(\bigcirc), 0 \cdot 10 \mathrm{~mm}$ $(\square)$ and $0.40 \mathrm{~mm}(\square)$. Activities were determined at $\mathrm{pH} 8.5$ using the spectrophotometric assay.

Fig. 3. Effect of phosphoenolpyruvate on the fructose bisphosphatase activity of the form $B$ isoenzyme at fixed AMP concentrations of $0(\bigcirc), 0.025 \mathrm{mM}(\bigcirc)$ and $0.10 \mathrm{mM}(\square)$. Plots of relative activity versus phosphoenolpyruvate concentrations are shown. The activities, measured by the spectrophotometric assay at $\mathrm{pH} 8.5$, are expressed as a percentage of the activity with $0.1 \mathrm{mM}$-fructose bisphosphate in the absence of both phosphoenolpyruvate and AMP, i.e.

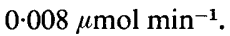

phosphate and sedoheptulose bisphosphate. The apparent $K_{\mathrm{m}}$ values obtained for fructose bisphosphate and sedoheptulose bisphosphate were $17 \mu \mathrm{M}$ and $15 \mu \mathrm{M}$, respectively, for both form A and form B. Form A was progressively inhibited by the substrates at concentrations higher than $0 \cdot 1 \mathrm{~mm}$. For both enzymes sedoheptulose bisphosphate was a linear competitive inhibitor of the fructose bisphosphatase activity (Fig. 1). The $K_{\mathrm{i}}$ values for sedoheptulose bisphosphate were $16 \mu \mathrm{M}$ for form A and $17 \mu \mathrm{M}$ for form B and closely resembled the values of the Michaelis constants. These results strongly suggest that in both cases a single protein possessed fructose bisphosphatase as well as sedoheptulose bisphosphatase activity.

Sigmoid kinetics were observed with increasing concentrations of $\mathrm{MgCl}_{2}$ in the presence of fixed concentrations of fructose bisphosphate (results not shown). Hill coefficients $(h)$ were calculated to be 1.7 for form $\mathrm{A}$ and 1.8 for form $\mathrm{B}$, indicating positive cooperativity in the binding of $\mathrm{Mg}^{2+}$. The $[\mathrm{S}]_{0.5}$ for $\mathrm{MgCl}_{2}$ was $0.26 \mathrm{~mm}$ and $0.36 \mathrm{mM}$ for form $\mathrm{A}$ and form B, respectively.

Some regulatory properties. The effect of various metabolites on the activity of the isoenzymes was studied. The results indicated that the enzymes were differently regulated by purine and nicotinamide nucleotides and ribulose bisphosphate (Table 3). Form A was inhibited by ATP but showed little sensitivity to AMP. A Hill plot of the inhibition data (not shown) yielded values of $\left[\mathrm{I}_{0.5}\right.$ for ATP of $0.6 \mathrm{~mm}$ and an interaction coefficient of 0.8 indicating a weak, negative cooperativity in the binding of ATP. While ATP was only a moderate inhibitor for form B, AMP exerted a strong allosteric inhibition on this enzyme. An interaction coefficient of 3.4 and an $[\mathrm{I}]_{0.5}$ value for AMP of $14 \mu \mathrm{M}$ were calculated. $\mathrm{NAD}^{+}$and, particularly, NADH were also effective inhibitors of form $\mathrm{B}$ whereas form A was only slightly inhibited by these nucleotides. In contrast, only form A was significantly inhibited by ribulose bisphosphate $\left([\mathrm{I}]_{0} \cdot 5 \mathrm{mM}\right)$.

Initial velocity studies revealed that phosphoenolpyruvate was an activator of form $\mathrm{B}$. Phosphoenolpyruvate did not effect the $K_{\mathrm{m}}$ value for fructose bisphosphate but increased 
the maximal velocity (Fig. 2) and had a $K_{\mathrm{a}}$ value of $40 \mu \mathrm{M}$. On the other hand, the activity of form A was inhibited $36 \%$ by phosphoenolpyruvate at $1 \mathrm{mM}$. The AMP inhibition of form B could be partially overcome by phosphoenolpyruvate (Fig. 3). The degree of cooperative interactions among the AMP sites was greatly diminished by phosphoenolpyruvate. In the presence of $0.4 \mathrm{~mm}$-phosphoenolpyruvate the Hill coefficient decreased to $2 \cdot 0$. In turn, the $[\mathrm{S}]_{0.5}$ for phosphoenolpyruvate, i.e. the concentration of phosphoenolpyruvate giving $50 \%$ activation, increased to $0.65 \mathrm{~mm}$ in the presence of $0.1 \mathrm{mM}$-AMP.

\section{DISCUSSION}

The hydrogen-oxidizing bacterium Nocardia opaca is able to form two distinct fructose bisphosphatases: form $\mathrm{A}$ is an inducible enzyme formed only during autotrophic growth, suggesting that it functions in the Calvin cycle, whereas form B is a constitutive enzyme synthesized during heterotrophic growth on pyruvate or fructose as well as under autotrophic conditions. This latter enzyme plays a gluconeogenic role during heterotrophic growth.

This is the first time that fructose bisphosphatase isoenzymes have been identified in an autotrophic bacterium. The existence of two fructose bisphosphatases in plant tissues, one located in the cytoplasm and the other in the chloroplasts, has recently been demonstrated for spinach leaves (Zimmermann et al., 1976, 1978). Two forms of the enzyme were also found in mammalian tissues. The fructose bisphosphatase isolated from muscle differs in its immunological properties and amino acid composition from the enzyme in kidney or liver (Enser et al., 1969; Tejwani et al., 1976).

The isoenzymes from $N$. opaca resemble the fructose bisphosphatases from other organisms in many properties. They have high affinities for their substrates, require $\mathrm{Mg}^{2+}$ or $\mathrm{Mn}^{2+}$ for activity and exhibit single $\mathrm{pH}$ optima in the alkaline range and are thus similar to the fructose bisphosphatase from the hydrogen bacterium Alcaligenes eutrophus (Abdelal \& Schlegel, 1974) and from the photosynthetic bacterium Rhodopseudomonas palustris (Springate \& Stachow, 1972a). Like the enzymes from several eukaryotic and prokaryotic sources (Van Tol et al., 1972; Rosen, 1966; Mukkada \& Bell, 1971), the N. opaca enzymes are stimulated by EDTA, but the chelating agent did not alter the $\mathrm{pH}$ optima. For ox liver fructose bisphosphatase, activation by EDTA was due to the removal of heavy metal inhibitors (Nimmo \& Tipton, 1975).

Like the fructose bisphosphatases from rat liver (Bonsignore et al., 1963), R. palustris (Springate \& Stachow, 1972a) and A. eutrophus (Abdelal \& Schlegel, 1974), but unlike the enzymes from Candida utilis (Rosen et al., 1965) and Escherichia coli (Fraenkel et al., 1966), the purified $N$. opaca enzymes functioned as both fructose bisphosphatases and sedoheptulose bisphosphatases. Identical $\mathrm{pH}$ optima, similar kinetic constants and the competitive inhibition of the fructose bisphosphatase activities by sedoheptulose bisphosphate strongly suggested that in both cases the activities were associated with the same protein. The sedoheptulose bisphosphatase activity of the form B isoenzyme was not observed in crude fractions but appeared in subsequent stages of purification, indicating that in vivo form B acts only as a fructose bisphosphatase. We are unable to explain this loss of substrate specificity during purification. The molecular weight of the enzyme (190000) did not change detectably during purification. However, although precautions against proteolysis were taken by using the proteolytic inhibitors phenylmethanesulphonylfluoride and EDTA, slight proteolytic damage cannot be excluded. The molecular weight of form B is significantly higher than that of form A (140000); the latter is similar to molecular weights reported for the enzyme from other organisms (130000 to 140000) (Springate \& Stachow, 1972a; Horecker et al., 1975).

The regulatory properties of the two isoenzymes from $N$. opaca differ in many respects. Form A, like the enzyme from most autotrophic bacteria (Springate \& Stachow, 1972b; Joint et al., 1972; Abdelal \& Schlegel, 1974), is inhibited by ATP and relatively insensitive 
to AMP. The physiological significance of the inhibition by ATP is unclear since the Calvin cycle must operate maximally when the energy supply is in excess. The inhibition of form A by ribulose 1,5-bisphosphate, which is the primary carbon dioxide acceptor molecule, can be interpreted as end-product inhibition of an early reaction of the Calvin cycle catalysed by fructose bisphosphatase.

Form B is severely inhibited by AMP. Thus, although $N$. opaca does not contain phosphofructokinase and degrades fructose preferentially via the Entner-Doudoroff pathway (Probst \& Schlegel, 1973), the gluconeogenic form B enzyme is regulated in the same way as the fructose bisphosphatases from heterotrophic organisms which use the EmbdenMeyerhof glycolytic pathway (Taketa \& Pogell, 1965; Fraenkel et al., 1966). The finding that phosphoenolpyruvate not only activated form B but also counteracted the inhibitory effect of AMP underlines the gluconeogenic role of this enzyme. This type of precursor activation of fructose bisphosphatase by phosphoenolpyruvate has also been reported for the enzymes from Flavobacterium thermophilum (Yoshida \& Oshima, 1971) and Bacillus licheniformis (Opheim \& Bernlohr, 1975). The strong inhibitory effects of $\mathrm{NAD}^{+}$and NADH on form B are surprising since their significance in the regulation of the enzyme is not clear. So far this is the only fructose bisphosphatase which has been reported to be inhibited by nicotinamide dinucleotides.

To summarize, the results suggest that the two fructose bisphosphatase isoenzymes of $N$. opaca play different physiological roles. During autotrophic growth form A catalyses the essential hydrolysis of both fructose bisphosphate and sedoheptulose bisphosphate in the Calvin cycle. Form B has a gluconeogenic function under heterotrophic growth conditions. Interestingly, indirect evidence has been obtained that in this strain the genes coding for the key autotrophic enzymes hydrogenase, phosphoribulokinase and ribulose bisphosphate carboxylase are located on a plasmid (Reh \& Schlegel, 1975; Ecker, 1977). It remains to be determined whether additional enzymes of the Calvin cycle, e.g. form A fructose bisphosphatase, are also coded on extrachromosomal DNA.

We wish to thank Mrs P. Schobert for skilful technical assistance.

\section{REFERENCES}

Abdelal, A. T. \& Schlegel, H. G. (1974). Purification and regulatory properties of fructose 1,6diphosphatase from Hydrogenomonas eutropha. Journal of Bacteriology 120, 304-310.

Aggag, M. \& Schlegel, H. G. (1973). Studies on a Gram-positive hydrogen bacterium, Nocardia opaca strain 1b. I. Description and physiological characterization. Archiv für Mikrobiologie 88, 299-318.

AmEs, B. N. (1966). Assay of inorganic phosphate. Methods in Enzymology 8, 115-116.

Bassham, J. A. (1971). The control of photosynthetic carbon metabolism. Science 172, 526-534.

Bonsignore, A., Mangiarotti, G., Mangiarotti, M. A., de Flora, A. \& Pontremoli, S. (1963). Cleavage of sedoheptulose 1,7-diphosphate by a purified rat liver diphosphatase. Journal of Biological Chemistry 238, 3151-3154.

Buchanan, B. B., Schürmann, P. \& Kalberer, P. P. (1971). Ferredoxin-activated fructose diphosphatase of spinach chloroplasts: resolution of the system, properties of the alkaline fructose diphosphatase component, and physiological significance of the ferredoxin-linked activation. Journal of Biological Chemistry 246, 5952-5959.
Buchanan, B. B., Schürmann, P. \& Wolosiuk, R. A. (1976). Appearance of sedoheptulose-1,7diphosphatase activity on conversion of chloroplast fructose-1,6-diphosphatase from dimer to monomer form. Biochemical and Biophysical Research Communications 69, 970-978.

ECKER, C. (1977). Nachweis der plasmidgebundenen, autotrophes Wachstum ermöglichenden Enzyme bei Nocardia. Ph.D. thesis, University of Göttingen, F.R.G.

Enser, M., Shapiro, S. \& Horecker, B. L. (1969). Immunological studies of liver, kidney, and muscle fructose 1,6-diphosphatases. Archives of Biochemistry and Biophysics 129, 377-383.

Fraenkel, D. G., Pontremoli, S. \& Horecker, B. L. (1966). The specific fructose diphosphatase of Escherichia coli: properties and partial purification. Archives of Biochemistry and Biophysics 114, 4-12.

Horecker, B. L., Melloni, E. \& Pontremoli, S. (1975). Fructose 1,6-bisphosphatase: properties of the neutral enzyme and its modification by proteolytic enzymes. Advances in Enzymology and Related Areas of Molecular Biology 42, 193226. 
JoInt, I. R., Morris, I. \& Fuller, R. C. (1972). Purification of a complex of alkaline fructose 1,6bisphosphatase and phosphoribulokinase from Rhodospirillum rubrum. Journal of Biological Chemistry 247, 4833-4838.

Mukkada, A. J. \& Bell, E. J. (1971). Partial purification and properties of the fructose 1,6-diphosphatase from Acinetobacter lwoffi. Archives of Biochemistry and Biophysics 142, 22-31.

Nimmo, H. G. \& Tipton, K. F. (1975). The purification of fructose 1,6-diphosphatase from ox liver and its activation by ethylenediaminetetraacetate. Biochemical Journal 145, 323-334.

Opheim, D. J. \& Bernlohr, R.W. (1975). Purification and regulation of fructose-1,6-bisphosphatase from Bacillus licheniformis. Journal of Biological Chemistry 250, 3024-3033.

Probst, I. \& Schlegel, H. G. (1973). Studies on a Gram-positive hydrogen bacterium, Nocardia opaca strain 1b. II. Enzyme formation and regulation under the influence of hydrogen or fructose as growth substrates. Archiv für Mikrobiologie 88, 319-330.

Racker, E. \& Schroeder, E. A. R. (1958). The reductive pentose phosphate cycle. II. Specific C-1 phosphatases for fructose 1,6-diphosphate and sedoheptulose 1,7-diphosphate. Archives o, Biochemistry and Biophysics 74, 326-344.

ReH, M. \& Schlegel, H. G. (1975). Chemolithoautotrophie als eine übertragbare autonome Eigenschaft von Nocardia opaca 1b. Nachrichten der Akademie der Wissenschaften in Göttingen. II. Mathematisch-Physikalische Klasse 12, 207216.

ReIland, J. L. (1971). Gel filtration. Methods in Enzymology 22, 287-321.

Rosen, O. M. (1966). Purification and properties of fructose 1,6-diphosphatase from Polysphondylium pallidum. Archives of Biochemistry and Biophysics 114, 31-37.

Rosen, O. M., Rosen, S. M. \& Horecker, B. L. (1965). Purification and properties of a specific fructose 1,6-diphosphatase from Candida utilis. Archives of Biochemistry and Biophysics 112, 411 420.
Schlegel, H. G., Kaltwasser, H. \& Gottschalk, G. (1961). Ein Submersverfahren zur Kultur wasserstoffoxydierender Bakterien: wachstumsphysiologische Untersuchungen. Archiv für Mikrobiologie 38, 209-222.

SchürmanN, P. \& Wolosiuk, R. A. (1978). Studies on the regulatory properties of chloroplast fructose-1,6-bisphosphatase. Biochimica et biophysica acta 522, 130-138.

Springate, C. F. \& Stachow, C. S. (1972a). Fructose 1,6-diphosphatase from Rhodopseudomonas palustris. I. Purification and properties. Archives of Biochemistry and Biophysics 152, 1-12.

Springate, C. F. \& Stachow, C.S. (1972b). Fructose 1,6-diphosphatase from Rhodopseudomonas palustris. II. Regulatory properties. Archives of Biochemistry and Biophysics 152, 13-20.

Taketa, K. \& Pogell, B. M. (1965). Allosteric inhibition of rat liver fructose 1,6-diphosphatase by adenosine 5'-monophosphate. Journal of Biological Chemistry 240, 651-662.

Tejwani, G. A., Pedrosa, F. O., Pontremoli, S. \& Horecker, B. L. (1976). The purification and properties of rat liver fructose 1,6-bisphosphatase. Archives of Biochemistry and Biophysics 177, 253264.

VAN Tol, A., Black, W. J. \& Horecker, B. L. (1972). Activation of rabbit muscle fructose diphosphatase by EDTA and the effect of divalent cations. Archives of Biochemistry and Biophysics 151, 591-596.

Yoshida, M. \& Oshima, T. (1971). The thermostable allosteric nature of fructose 1,6-diphosphatase from an extreme thermophile. Biochemical and Biophysical Research Communications 45, 495-500.

ZimmermanN, G., Kelly, G. J. \& Latzko, E. (1976). Efficient purification and molecular properties of spinach chloroplast fructose 1,6-bisphosphatase. European Journal of Biochemistry 70, 361-367.

ZimmermanN, G., Kelly, G. J. \& Latzko, E. (1978). Purification and properties of spinach leaf cytoplasmic fructose-1,6-bisphosphatase. Journal of Biological Chemistry 253, 5952-5956. 